\title{
Do vídeo-ativismo à Vía Digital: uma nova década do documentário argentino
}

\author{
Marcel Gonnet Wainmayer*
}

Resumo: Entre 2007 e 2015 a produção de documentários na Argentina atingiu o maior volume e diversidade da sua história, com a criação de um edital específico para obras de baixo orçamento em formato digital. Em boa parte, essas medidas foram produto da pressão de grupos e associações de documentaristas surgidos ao calor da crise de dezembro de 2001, que reclamavam por uma democratização do acesso aos recursos.

Palavras-chave: fomento audiovisual; documentário; baixo orçamento; políticas públicas.

Resumen: Entre 2007 y 2015 la producción de documentales en Argentina alcanzó el mayor volumen y diversidad de su historia, a partir de la creación de una línea de fomento específica para largometrajes digitales de bajo presupuesto. En gran parte, estas medidas fueron el resultado de la presión de grupos y asociaciones de documentalistas surgidos al calor de la crisis de diciembre de 2001, que reclamaban una democratización del acceso a recursos públicos.

Palabras clave: fomento audiovisual; documental; bajo presupuesto; políticas públicas.

Abstract: Between 2007 and 2015, the production of documentaries in Argentina reached the greatest number and diversity in its history due to the creation of a call for low budget works in digital formats. To a large extent, these measures were the result of pressures coming from groups of documentary filmmakers that emerged in the heat of the December 2001 crisis, calling for the democratization of access to resources. Keywords: audiovisual development; documentary; low budget; public policy.

Résumé : Entre 2007 et 2015, la production de documentaires en Argentine a atteint le plus grand nombre et la plus grande diversité de son histoire, en raison de la création d'un appel d'offre pour des œuvres à petit budget en format numérique. Ces mesures résultent dans une large mesure des pressions exercées par les groupes de documentaristes qui ont émergé au plus fort de la crise de décembre 2001 et ont appelé à la démocratisation de l'accès aux fonds publics.

Mots-clés : développement audiovisuel ; documentaire ; petit budget ; politique publique.

* Universidade Federal Fluminense - UFF, Instituto de Arte e Comunicação Social - IACS, Programa de Pós-graduação em Comunicação da Universidade Federal Fluminense - PPGCOM UFF. 24210-201, Niterói (RJ), Brasil.

E-mail: marcelgonnet@gmail.com

Submissão do artigo: 25 de outubro de 2018. Notificação de aceitação: 22 de janeiro de 2019. 
No final de 2001, a grave crise econômica que atravessava a Argentina e o confisco das contas bancárias pelo governo levaram a que, nos dias 19 e 20 de dezembro, grandes manifestações nas maiores cidades do país forçassem a renúncia do então presidente Fernando De la Rua, o que abriu um período de instabilidade política e repressão que provocou dezenas de mortes, conhecido como o "Argentinazo". Em duas semanas, o país foi comandado por 5 presidentes da linha sucessória. Nesse contexto, as organizações de desempregados (chamados de piqueteros ${ }^{1}$ ) e setores médios das cidades organizaram assembleias nos bairros, e se produziram ocupações de centenas de fábricas e outros espaços, num processo de mobilização popular que se estendeu por mais de um ano.

Poucos dias antes dessa rebelião popular, entre 6 e 12 de dezembro, o Grupo de Cine Insurgente organizou o Ciclo de Cine Piquetero na Sala 1 do Cine Cosmos, na Avenida Corrientes, no centro de Buenos Aires. A convocatória somou vídeo-ativistas de distintos setores que buscavam exibir seus materiais e discutir o lugar das imagens no processo político e social que já havia começado.

Entre os documentários exibidos estavam: Matanza (1998, 74 min.), do Grupo Documental $1^{\circ}$ de Mayo; Diablo Familia y Propiedad (1999, 90 min.), com direção de Fernando Krichmar, do Grupo de Cine Insurgente; Piqueteros se escribe con $P$ de piedra (2001, 25 min.) e Organización y lucha (2001, 25 min.), realizações coletivas do grupo El Cuarto Patio; Agua de Fuego (2001, 74 min.), com direção de Candela Galantini, Sandra Godoy e Claudio Remedi, do Grupo Boedo Films; El Rostro de la Dignidad (2001, 60 min.), dirigido por Fabián Pierucci, do Grupo Alavio; Un Fantasma recorre la Argentina (2001, 41 min.), realização coletiva do Grupo de Cine Ojo Obrero; Piketeros (2000, 20 min.), de Juan Riggirozzi; ¿Piqueteros? Sí, piqueteros (2001, 31 min.) e Hasta donde dea... (2001, 32 min.), dirigidos por Pablo Navarro Espejo, do grupo de cinema Adoquin.

Ao todo foram exibidos 20 documentários, entre curtas e longas-metragens produzidos em suporte Betacam, MiniDV e até SuperVHS, com diferentes enfoques e registros, que pela primeira vez retratavam movimentos de desempregados sob uma perspectiva independente, questionando os estereótipos com que a televisão e a grande mídia os tinha retratado até então.

Na proposta do Ciclo de Cine Piquetero se estabeleciam relações entre estes trabalhos e a herança de grupos das décadas de 1960 e 1970 como Cine

1. O nome piquetero surge da prática de realizar bloqueios nas estradas (piquetes) como forma de protesto, organizados durante a década de 1990 principalmente pelos desempregados das explorações petroleiras no sul do país. O nome se estendeu depois a todos os movimentos de desempregados. 
de la Base, Cine Liberación e Realizadores de Mayo, sobretudo nos aspectos relativos à distribuição, sempre em espaços alternativos e com recursos e organização própria (Campodónico, 2005; Dodaro et al., 2007; Marrone et al., 2011).

Em fevereiro de 2003, alguns dos filmes foram convidados para o $53^{\circ} \mathrm{Fes}-$ tival de Cinema de Berlim, como parte do $33^{\circ}$ Foro Internacional do Novo Cinema, por iniciativa do programador Peter B. Schumann. Até então o festival apenas exibia material em suporte fílmico, mas Schumann explicou ante a audiência que tinham aceitado formatos de baixa definição devido à importância política do material. Os ingressos para as exibições do cinema piquetero na Berlinale se esgotaram rapidamente, e novas sessões foram agregadas fora do programa no Instituto Iberoamericano.

O interesse foi tão grande que na sua passagem por Berlim, Fernando Krichmar, do Grupo de Cine Insurgente, foi entrevistado pelo cineasta e escritor Alexander Kluge no seu programa de televisão. Na entrevista, que permaneceu inédita, Kluge perguntava sobre a realidade argentina desse momento, e sobre a organização dos setores da cultura durante a rebelião popular do 19 e 20 de dezembro de 2001, além de analisar a mirada do cinema piquetero:

AlexANDer Kluge: Existe uma frase na obra de Bertolt Brecht: "Olhar a boca do povo não é o mesmo que tentar falar com a voz do povo" ${ }^{2}$. Vocês parecem olhar a boca do povo...

FERNANDO KRICHMAR: Não somente isso. Tentamos que as produções sejam trabalhadas de forma orgânica dentro dos mesmos movimentos sociais. A nossa câmera sempre está do lado de quem recebe as balas, nunca do lado da polícia. Quando fazemos projeções, as pessoas geram debates muito interessantes, porque sentem que pela primeira vez é considerado seu ponto de vista. É uma postura da câmera com certa carga moral, uma tomada de posição, representa um tipo de ideologia. Em algumas produções, o corte final foi montado em assembleia. A gente fazia um rascunho, o mostrávamos, e as pessoas opinavam. Se a gente toma o sistema da mídia como algo estabelecido, imutável, teremos que nos conformar com que somente 2 milhões de pessoas assistam ao cinema na Argentina, mas somos 40 milhões de habitantes. A gente leva o cinema aos bairros, onde muitas vezes as pessoas nunca assistiram ao cinema.

KLUGE: É um instrumento de propaganda...

2. Dem Volk aufs Maul schauen, aber nicht nach dem Mund reden. A frase utilizada por Kluge é de difícil tradução. É na verdade uma adaptação de Brecht da recomendação que Martin Lutero dava aos tradutores da Bíblia ao idioma alemão, "olhar a boca do povo". Para Lutero, era necessário que as escrituras admitissem a emergência da língua vernácula, que permitissem a expressão popular. A advertência agregada por Brecht ("não é o mesmo que tentar falar com a voz do povo") apontava provavelmente aos perigos da apropriação pelo fascismo de elementos da cultura popular (Westhelle, Vitor. Transfiguring Luther: The Planetary Promise of Luther's Theology. Cascade Books, Eugene, Oregon. 2016). 
KRICHMAR: É um instrumento de propaganda e uma arma de luta. Cremos que a maior arma de subjetivação que possui a burguesia neste momento é a imagem audiovisual. E assim como temos que enfrentar as suas forças repressivas, também temos que enfrentar as suas forças simbólicas, para gerar uma subjetividade que permita acreditar numa mudança. ${ }^{3}$

Os grupos e realizadores destes documentários vinham de diversas experiências e vertentes organizativas. Ainda que muitos pertencessem a movimentos sociais, e poderiam ser enquadrados na figura do ativista político que começa a fazer registros em vídeo, outro setor tinha maior experiência, e já desde a década de 1990 organizava mostras de documentário político e disputava espaços sindicais e associativos em universidades e escolas de cinema. A convergência da vertente vídeo-ativista, por um lado, e a vertente sindicalprofissional por outro, resultou numa série de organizações que reuniram os realizadores durante mais de uma década.

Um dos primeiros grupos foi Argentina Arde, que surgiu no calor das manifestações de dezembro de 2001 como um coletivo de contrainformação que produzia, além de vídeo, publicações escritas e mostras fotográficas, e que atuou por mais de um ano com funcionamento em assembleia e presença em diversas regiões do país. Alguns deles fundaram ao mesmo tempo a Asociación de Documentalistas de la Argentina (ADOC), como um encontro de vários coletivos de realizadores, que mais tarde foi ampliada com a criação de DOCA, Documentalistas Argentinos. Outros grupos como Realizadores Integrales de Cine Documental (RDI) e diversos núcleos em todo o país representaram mais aos ativistas organizados a partir de escolas de cinema e universidades.

Todas estas experiências, somadas à ação de outros grupos e organizações de documentaristas com mais experiência, como ADN (Asociación de Directores y Productores de Cine Documental), e a grupos ainda mais antigos como Cine Ojo, que já tinham batalhado pela Ley de Cine de 1994 ( $\mathrm{N}^{\circ}$ 17.741), permitiram abrir um processo de diálogo, protesto e negociação com as autoridades do Instituto Nacional de Cine y Artes Audiovisuales (INCAA), a partir do reconhecimento da necessidade de um novo regime de apoio às produções de documentário independente de baixo orçamento.

O resultado das negociações foi a Resolución 632/2007 do INCAA, de abril de 2007, que abriu a possibilidade dos realizadores acederem aos apoios, mas a sua lenta implementação gerou novos protestos. Um dos mais importantes foi o do dia 17 de agosto de 2007, quando dezenas de documentaristas bloquearam a Rua Lima, no centro da cidade de Buenos Aires, e colocaram as suas câmeras apontando ao edifício do INCAA. A ação, conhecida como o "Camarazo", se

3. Entrevista realizada em fevereiro de 2003. Material cedido por Gülsen Döhr e Alexander Kluge, DCTP (Düsseldorf, Alemanha). 
propunha a denunciar o uso discricionário dos fundos de fomento, e a reclamar equidade e democratização do acesso aos recursos, e especialmente a criação de júris representativos para a análise dos projetos. Finalmente, o regime de apoios ao documentário digital começou a funcionar no final de 2007. Dois anos mais tarde, a Ley de Servicios de Comunicación Audiovisual (26.522) criou novos canais de distribuição e iniciou a implementação do sistema de $T e$ levisión Digital Abierta (TDA). Proponho-me analisar esse período inaugurado pela Via Digital Documental. Trata-se de uma extensão do trabalho empreendido na dissertação de Mestrado «Um cinema de pessoa física: A figura do "realizador integral" nas políticas de fomento ao documentário na Argentina», defendida em agosto de 2017 no Programa de Pós-graduação em comunicação da Universidade Federal Fluminense (PPGCOM UFF), sob orientação do professor Antônio Carlos 'Tunico' Amâncio.

\section{Um cinema de pessoa física}

O regime de apoios ao documentário conhecido como a Via Digital Documental, que se pôs em prática no final de 2007, trouxe uma inovação relevante: não exigia experiência prévia aos realizadores, quando nos outros editais de fomento do INCAA, a exceção das convocatórias Historias breves e outros editais para curtas de ficção, se estabeleciam requisitos que claramente dificultavam a realização de primeiros filmes.

A Vía Digital Documental, estabelecida com a Resolución 632/2007 do INCAA (depois modificada pelas resoluções 1885/2008, 1023/2012, e 982/ 2013), significou o reconhecimento de novas modalidades de produção, que começaram a ser contempladas pela destinação de recursos públicos. No entanto, logo se identificou que ainda era necessária mais uma porta de entrada ao sistema de fomento, para contemplar aos setores mais jovens e inexperientes, com um edital de desenvolvimento e outro de finalização.

Nas associações de documentaristas se organizou a eleição dos jurados, buscando que fossem realizadores com experiência, ou críticos ou professores relacionados ao documentário.

Entre 2007 e 2015, 542 projetos foram financiados para produção, 117 projetos aprovados para sua etapa de desenvolvimento, e 53 filmes com o benefício na pós-produção. 
Apoios para Produção, Desenvolvimento e Pós-produção por Vía Digital Documental (2007-1015). Documentários produzidos pelas resoluções 632/2007; 1885/2008; 1023/2012; e 982/2013

\begin{tabular}{|r|r|r|r|}
\hline \multirow{2}{*}{ Ano } & \multicolumn{3}{|c|}{ Tipo de apoio } \\
\cline { 2 - 4 } & \multicolumn{1}{|c|}{ Produção } & Desenvolvimento & Pós-produção \\
\hline 2007 & 32 & 1 & \\
\hline 2008 & 48 & 10 & 8 \\
\hline 2010 & 50 & 6 & 3 \\
\hline 2011 & 46 & 20 & 7 \\
\hline 2012 & 62 & 34 & 9 \\
\hline 2013 & 93 & 14 & 7 \\
\hline 2014 & 58 & 15 & 7 \\
\hline 2015 & 46 & 17 & 53 \\
\hline Totais & 108 & 117 & 5,9 \\
\hline Média anual & 542 & 13,0 & \\
\hline
\end{tabular}

Fonte: Elaboração própria, com base nas listas de aprovação e listas de pagamentos publicadas no sítio web do INCAA.

É preciso esclarecer que esta tabela esta construída somente a partir da informação disponível, pelo que deve ser considerada ainda como estimativa quanto ao conhecimento atual sobre esta linha de fomento. E ainda que se tenha reconstruído uma lista ano a ano de projetos aprovados, o ponto de corte destas séries anuais é difícil de se estabelecer com a informação que oferecem as publicações do INCAA.

Feitas estas ressalvas, a revisão da informação e as estimativas realizadas permitem extrair algumas conclusões iniciais:

- Dos 542 projetos financiados para produção, foram detectadas 44 empresas beneficiadas, ou seja, $8,1 \%$ do total. O resto recebeu o benefício como pessoa física.

- De 117 projetos financiados para desenvolvimento, apenas $4(3,4 \%)$ foram apresentados por empresas produtoras.

- Nenhum dos 53 benefícios para a pós-produção de filmes já finalizados foi outorgado a empresas.

Em termos financeiros, o gasto para essa produção de nove anos, em todas suas linhas de apoio, não superou os 23 milhões de dólares, se consideradas as cotizações de cada ano. A média é um pouco mais de 2,5 milhões de dólares ao 
ano. Com esses recursos, a Vía Digital Documental viabilizou anualmente a produção de cerca de 60 longas metragens, o desenvolvimento de 13 projetos, e a pós-produção de 6 filmes, para finalizar longas-metragens que não obtiveram apoio por outras vias do INCAA.

Trata-se, sem dúvida, da maior produção de longas documentários na história da Argentina. Se considerarmos por exemplo o ano de 2013, na Argentina se estrearam 399 filmes; desses, 166 foram de produção nacional, e, desse total, 82 foram documentários, ou seja, 49,4\%: a metade da produção nacional estreada em salas (INCAA, 2013).

\section{O desafio da exibição}

Durante o período analisado, a estreia em salas de documentários digitais foi matéria de tensões entre o INCAA e as associações de documentaristas, que mantiveram uma pressão constante a respeito, reivindicando ajuda à difusão e distribuição, e geraram espaços de difusão próprios tanto dentro do sistema de salas estatais chamado Espacios INCAA, com ciclos como a Semana ADN, a Muestra DOCA e com estreias individuais em salas do circuito, assim como em redes independentes. $\mathrm{O}$ apoio à difusão e ao lançamento destes filmes resultam ser elementos vitais para qualquer estratégia de estreia em salas, dadas as poucas oportunidades de aceder ao público em circuitos comerciais.

Esta tensão entre a exibição em salas e na televisão pública emana das próprias resoluções que criaram a Vía Digital, que estabelecem que os fundos provêm da "aquisição de direitos para sua exibição televisiva" (resoluções 632 e 1885). Somente em segundo lugar se aclara que para "a exibição em salas ou lugares de exibição cinematográfica, mostras, festivais ou qualquer outra atividade de difusão, a mesma poder-se-á realizar com o consentimento do titular da obra" (Resolución 982/13 INCAA).

Todas estas políticas de fomento voltadas para formatos digitais implementadas na Argentina têm buscado dar resposta a demandas de novos realizadores, novas regiões e novas formas de produção, com novas dinâmicas sociais e econômicas. No entanto, quanto à distribuição e exibição do documentário se acentuou o gargalo de que sofre o mercado argentino em geral. Apesar dos esforços do INCAA de manter uma rede de mais de 50 salas de exibição próprias em todo o país, que permite que dezenas de documentários tenham estreia em sala, apenas alguns filmes conseguem se manter em cartaz por mais de uma semana.

Os recursos para a promoção de lançamento de obras nacionais geralmente são orientados a empresas distribuidoras, o que supõe uma clara divisão entre as produções de baixo orçamento (de pequenas empresas ou de pessoas físi- 
cas), e os títulos realizados com orçamentos maiores. E no modelo do negócio cinematográfico, os números de público têm tudo a ver com o investimento em publicidade.

O cumprimento da "media de continuidade" (Resolución 2016/04 INCAA) para a permanência nas salas estabelece que os filmes que não alcançam os 500 espectadores na primeira semana não possam continuar em exibição na segunda semana. A falta de difusão das estreias realimenta esta maquinaria frustrante. São poucos os casos nos quais um filme nacional, seja ficção ou documentário, logra superar os 10.000 espectadores.

Com poucas salas à disposição, e sem apoio ao lançamento nem à promoção, os documentários da Vía Digital não puderam romper com a sorte mais geral do cinema argentino, inclusive do cinema comercial nacional, quanto à baixa quantidade de espectadores. São poucos os casos de documentários que superaram a barreira dos 10.000 espectadores em sala. É interessante trazer aqui dois casos, porque representam produções de documentário político relacionadas aos grupos que participaram dos processos de instauração da Vía Digital Documental.

Seré Millones (2013. $103 \mathrm{~min}$.) documentário dirigido por Omar Neri, Fernando Krichmar e Mónica Simoncini, integrantes dos grupos Mascaró e Cine Insurgente, relata a historia de dois empregados do Banco Nacional de Desarrollo (BANADE), militantes do Ejército Revolucionario del Pueblo, que em janeiro de 1972 decidem organizar um assalto no seu próprio lugar de trabalho. Se trata da maior "expropriação" a um banco na historia argentina, e os fundos financiaram diversas ações guerrilheiras em vários países. Nem um centavo foi para o uso pessoal dos assaltantes. A câmera volta com os protagonistas ao lugar dos fatos, quarenta anos depois, com a desculpa de filmar uma ficção sobre o caso. O filme é narrado com muito humor, e obteve boas críticas e visibilidade na imprensa. Se manteve durante 2 meses em cartaz no cinema Gaumont de Buenos Aires, dependente do INCAA, e superou os 10.000 espectadores somente nessa sala.

É muito pouco se comparado com os 3.308 .703 espectadores da animação Monsters University [Estados Unidos, 2013, 96 min.], o filme de maior público de 2013, ou mesmo com os 2.119.601 de Metegol [Argentina, 2013, 104 min., dirigida por Juan José Campanella], o filme nacional mais visto. No entanto, Seré Millones gerou uma media de 101 espectadores por sala, o que supera aos 96 espectadores por sala da animação norte-americana, e é quase o dobro dos 66 espectadores por sala de Metegol. ${ }^{4}$ (La Izquierda Diario, 9 de dezembro de 2014).

4. "Qué hacer con el cine documental", La Izquierda Diario, 9 de dezembro de 2014. Disponível em: http://laizquierdadiario.com/spip.php?page=gacetilla-articulo\&id_article=7989 
A comparação aponta ao problema da quantidade de salas que ocupam os filmes distribuídos pelas majors (o que também se aplica a grandes produções comerciais nacionais como Metegol, distribuída pela United International Pictures, propriedade da Universal e da Paramount), que monopolizam o mercado exibidor.

Outro exemplo interessante é o documentário ¿Quién mato a Mariano Ferreyra? (2013, 95 min.), dirigido por Julián Morcillo e Alejandro Rath, do grupo de cinema Ojo Obrero, que reconstrói a trama detrás do assassinato do jovem militante de esquerda Mariano Ferreyra, perpetrado por burocratas do sindicato Unión Ferroviaria em outubro de 2010. A estreia do filme foi parte da campanha pela demanda de justiça de um vasto setor de esquerda, e coincidiu com o final do processo judicial, que ocorreu em abril de 2013 e terminou com a condenação do maior dirigente da Unión Ferroviaria, José Pedraza. O filme foi exibido em cinco salas de Buenos Aires e em salas de outras cidades como Córdoba, Tucumán e Bahía Blanca. Durante a primeira semana alcançou os 4.500 espectadores, e nas seguintes superou largamente a meta de 10.000 . Os números oficiais do INCAA, mais conservadores que os controles realizados pelos realizadores, outorgaram ao filme uma média de 41 assistentes por função, contabilizada para 128 funções (INCAA, 2013). O interessante do caso é que os realizadores, a partir da urgência que impunha o processo judicial, adaptaram os tempos de produção e utilizaram a estreia em salas para intervir no plano político.

Por outro lado, é possível encontrar exemplos de documentários da Vía Digital multipremiados no exterior, que não conseguiram público nas salas do país. O caso mais notável talvez seja o do filme El Ambulante (2009, 84 min.), dirigido por Eduardo de la Serna, Lucas Marcheggiano e Adriana Yurcovich, que retrata o trabalho de Daniel Burmeister, um artista que percorre o interior da Argentina para realizar filmes artesanais, com histórias interpretadas por vizinhos de pequenos povoados e atores não profissionais. Burmeister produz ficções realizadas com equipamento Super-VHS e na tradição do teatro popular ambulante, filmes que ele mesmo dirige, edita e exibe no próprio povoado no qual filmou. Trata-se de um documentário de observação, que segue a Burmeister nas suas viagens num velho carro enferrujado. Teve estreia no International Documentary Filmfestival Amsterdam (IDFA), obteve 18 prêmios em festivais internacionais, como o Festival de Abu Dhabi, o Festival de Cinema Latino de Los Angeles, o Dok Fest de Munich, FIDocs de Santiago de Chile, o Prêmio do Público no Festival Internacional de Cine Independiente de Buenos Aires (BAFICI), e o Prêmio do Público no Docs Barcelona, além de participar em mais de 60 festivais e mostras importantes como o Hot Docs Canadá, e os 
festivais de Londres, Toulouse, Biarritz, San Francisco, e o MOMA de Nova York. No entanto, com sua estreia em salas na Argentina, em setembro de 2010, conseguiu a exígua cifra de 1.693 espectadores.

A lógica comercial reinante no setor da exibição obriga a que os documentários sejam programados por pouco tempo, com muitas sessões diárias e em poucas salas, uma prática que se estende também às salas dependentes do INCAA.

Estas brechas entre as lógicas industriais de produção e exibição e a realização de documentário de baixo orçamento se manifestaram em diferentes níveis. Em termos de práticas produtivas, entre os realizadores da Vía Digital as relações se expandiram além dos limites projetados por cada filme. Nas diferentes cidades, os realizadores começaram a intercambiar serviços técnicos e a intervir uns nos filmes dos outros. Desde o ponto de vista das prestações de contas, esta prática permitiu que se criassem verdadeiras redes de trabalho.

Estas redes de serviços paralelas às do circuito industrial, ainda que criaram alguns conflitos com sindicatos e associações de autores, por outro lado garantiram uma liberdade criativa que permitiu a muitos realizadores fugir de formatos, cânones e imposições procedentes, sobretudo das estéticas das produções de televisão.

É o caso de Gustavo Fontán, diretor de Elegía de abril (2010, 64 min.), um documentário com fortes elementos de ficção, que se centra nas disputas de dois irmãos sobre a memória do pai, o poeta Salvador Merlino, que morreu pouco tempo antes da publicação do seu último livro. Depois de 50 anos empilhados no armário, a câmera registra o momento em que o bisneto de Merlino rasga os pacotes de livros, e segue o resultado desta irrupção do passado na vida dos velhos irmãos.

Para Fontán, ainda que a Vía Digital

restringe os subsídios somente ao documentário, permitiu que se fizesse uma enorme quantidade de filmes diversos, distintos, rebeldes, livres. Os comitês de seleção são propostos pelas associações de documentaristas e isso abre um leque muito amplo de olhares e interesses. Sempre defendemos uma concepção ampla do documentário, e nos diferenciamos do documentário mais televisivo. Por isso, a Vía Digital foi durante estes dez anos um enorme campo de diversidade e experimentação. ${ }^{5}$

É importante estabelecer também qual é a relação entre a Vía Digital Documental e a televisão pública. A Resolución 632/2007, que inaugurou esses editais, esclarece que os fundos se originam em pagamentos adiantados de direitos de exibição em televisão, e pouco se diz a respeito da estreia em salas de cinema.

5. Entrevista a Gustavo Fontán. 
Enquanto crescia a produção de documentários digitais, no Congresso argentino avançavam os acordos para a criação de um novo sistema de televisão digital. O lançamento em 2010 do canal INCAAtv, com programação de 24 horas de cinema argentino, como parte de um pacote de 16 novos sinais de televisão digital do Estado, permite rebater, em parte, o argumento de que os filmes da Vía Digital não tinham uma distribuição final garantida. A partir desse momento, começaram a ser exibidos por um sistema de TV gratuito, de alta definição e com cobertura nacional.

\section{As ficções de um cinema industrial}

As experiências resenhadas acima representaram práticas alternativas ao modelo de produção industrial, resistências que na história da cinematografia da Argentina se concretizaram muitas vezes na realização de documentários.

O brasileiro Paulo Emílio Salles Gomes parece estar falando também do caso argentino quando reconhece o crônico fracasso das políticas de fomento industrialista no Brasil, que nunca foram além de garantir uma "pequena reserva de mercado para o produto nacional", e que já em 1973 ele chamava de "respiradouro para o nosso cinema de ficção" (Sales Gomes, 2016: 93).

A produção de documentário, afogada pelo modelo de controle estatal primeiro, e esquecida pelas políticas de fomento industrial depois da década de 1950, manteve, no entanto, certa capacidade de se reinventar, com "surtos" menos relacionados com investimentos econômicos do que com o aproveitamento de avanços tecnológicos e o surgimento de projetos de mudança social e política.

Historicamente, se considerarmos que o crescimento internacional de Hollywood foi baseado mais na agressiva concentração dos setores da distribuição e da exibição do que na imposição de critérios de produção (Bernardet, 1979: 11), poucas eram as opções que restavam para os países desenvolverem suas cinematografias, se não começar a produzir e distribuir, nas condições e nas formas nas quais podiam, e tentar encontrar espaços para a exibição com diferentes disposições.

O que interessa aqui é colocar em discussão as políticas de fomento de corte industrialista, e sobretudo ampliar a análise além dos limites que impõe a visão de mercado, para entender a produção cinematográfica não somente em seu aspecto econômico,

mas principalmente, pelo intangível e cultural - sua capacidade de incidir sócio e culturalmente nos imaginários coletivos e individuais, produzindo e reproduzindo valores que atuam na manutenção ou na transformação da ordem social. É evidente, portanto, a necessidade de cultivar tanto uma reflexão crí- 
tica a respeito da hegemonia de Hollywood - e suas implicações econômicas, políticas e culturais - quanto uma visão autocrítica do papel desempenhado por grupos sociais locais no processo de configuração dessa hegemonia. (Cabral, 2014: 139).

A economia política da produção de cinema geralmente tem estabelecido que o público alvo das políticas públicas de fomento dos países sejam as empresas produtoras, distribuidoras e exibidoras, e tem considerado menos o apoio direto a pessoas físicas, isto é, diretores e artistas.

São poucos os casos na região de apoios para a realização audiovisual destinados a pessoas físicas. Em geral existem instrumentos limitados (seja pela quantidade de recursos ou pela sua cobertura regional), e são outorgados à produção de curtas ou mais comumente ao desenvolvimento de projetos de longas que depois de "desenvolvidos" devem entrar nos esquemas de financiamento normais, de subsídios ou créditos outorgados a empresas.

Boa parte do financiamento internacional de projetos é atada à associação entre empresas produtoras de dois ou mais países (tal como estabelecem, por exemplo, os acordos de coprodução entre a Argentina e o Brasil), e se existem fundos de desenvolvimento de projeto na modalidade de bolsas internacionais (Ibermedia, Hubert Bals Fund, IDFA Bertha Fund, Alter-Ciné e outros), são menos numerosos os apoios à produção destinados diretamente a realizadores.

Esse modelo de organização de viés empresarial, quase unanimidade entre os instrumentos de fomento de toda a região, estabelece que os destinatários dos apoios ou créditos devem ser empresas: que contratam pessoal (um diretor, um roteirista, um produtor, etc.), enquadradas nas disposições legais previstas para empresas (a disposição de um local, mas sobretudo a disposição de capital), e que cumprem com as obrigações fiscais previstas para entidades comerciais.

Por outro lado, os avanços da tecnologia digital no cinema modificaram radicalmente as formas de produção, eliminando especialidades e áreas completas do processo, o que também acarretou uma mudança em outros setores de poder empresarial, tanto na distribuição como na exibição. Na Argentina, como em outros países, nos últimos anos a digitalização alcançou quase o total da produção, tanto de ficção como de documentário, e acelerou o processo de convergência entre cinema, televisão e transmissões de dados pela Internet. Nas últimas décadas têm surgido novos players no mercado, e também novos realizadores com propostas que colocam em tensão o modelo prévio.

Não é um processo novo: desde o nascimento do cinema, cada avanço tecnológico tem sepultado a uns e reforçado a vocação de outros de incorporarse ao mercado. 
A aparição do "pensamento industrial" no cinema da Argentina e do Brasil se opôs ao modelo "culturalista" associado tradicionalmente à intervenção do Estado no fomento ao documentário (Autran, 2004: 228). Neste marco, os modelos de televisão alternativa e a produção de documentário "artesanal" são vistos desde a perspectiva da geração de espaços alternativos, já não associados ao discurso do Estado, mas como "esferas públicas" nas quais se tornam visíveis experiências sociais, políticas e estéticas nos confins dos domínios do cinema industrial. (Negt e Kluge, 1993: 80).

\section{Uma esfera pública alternativa}

Como já assinalamos, na Argentina as mobilizações sociais de dezembro de 2001 e suas ressonâncias marcaram a emergência de novos sujeitos na produção audiovisual, que colocaram em discussão as políticas culturais e demandaram uma democratização do acesso aos fundos para produção cinematográfica. O estabelecimento da Vía Digital foi o resultado de um longo processo de mobilização e de negociações impulsionadas pelos realizadores hoje organizados em diversas associações. Estes novos sujeitos, que produziam com orçamentos baixíssimos e sem apoio do Estado, e que criaram organizações de novo tipo, representaram uma posição contra-hegemônica, tanto frente à indústria nacional, quanto aos monopólios estrangeiros.

É interessante estabelecer aqui um paralelo com o surgimento do Novo Cinema Alemão da década de 1960, para retomar o pensamento de Alexander Kluge, uma das suas principais figuras. No estudo preliminar a Esfera Pública e Experiência (1972), livro escrito por Kluge em colaboração com Oskar Negt, a historiadora Miriam Hansen aponta que a produção do Novo Cinema teve de enfrentar, ao mesmo tempo, duas oposições concretas:

Quando em 1962 os jovens cineastas que assinaram o Manifesto de Oberhausen anunciaram a "morte do velho cinema", os esforços para impulsionar um cinema jovem na Alemanha foram dirigidos em primeiro lugar à instituição de um sistema de subsídio federal para primeiros filmes, e para estabelecer escolas e ensino de cinema com financiamento do Estado. O inimigo nesta luta era um monstro de duas cabeças: a indústria doméstica moribunda (marcada por algumas continuidades com o Terceiro Reich em termos de estrelas, diretores e gêneros), e as majors norte-americanas que efetivamente controlavam o mercado da Alemanha Ocidental através de práticas monopolistas de distribuição e exibição (Miriam Hansen apud, Negt \& Kluge,1993).

A trajetória desses realizadores nas duas décadas seguintes mostra outros elementos interessantes para pensar o caso argentino, já que em 1979, as mudanças nas disposições de fomento na República Federal da Alemanha permitiram que se outorgassem subsídios para primeiros filmes e projetos de baixo 
orçamento, e até fundos para pequenos distribuidores e exibidores, assim como para cinemas comunitários.

No entanto, na década seguinte se discutiram medidas neoliberais de abertura do sistema de televisão para o capital privado, pelo que os realizadores organizados em torno de Kluge pressionaram por estabelecer espaços para emissões culturais e jornalísticas (na prática, uma espécie de cota para o documentário) na programação dos novos canais privados. Já em 1972, com Esfera pública e experiência, Negt e Kluge tinham lançado uma forte crítica à burocracia do sistema estatal de televisão, dominado na Alemanha por setores conservadores. As novas medidas abriram uma brecha que os realizadores tentaram aproveitar. Kluge começou a produzir televisão, e desde 1985 mantém uma produtora (Development Company for Television Program, DCTP) que gera material a ser emitido por canais privados de entretenimento leve.

Ante a suposta contradição de Kluge, que desde a década de 1960 tinha lutado pelo financiamento público para o cinema, de ter passado a produzir para a televisão privada, o brasileiro Arlindo Machado assinala que o trabalho do diretor alemão prova que "a demanda comercial e o contexto industrial que marcam a televisão não inviabilizam necessariamente a criação artística ou a intervenção crítica, quando há força política e vontade transformadora suficientes para isso" (Machado, 2007: 68).

Como indica Hansen, para Kluge, se trata de abrir espaço na mídia comercial para "contraproduções, programas que ao mesmo tempo aprendam de e compitam com o inimigo no mais avançado nível técnico e econômico" (Miriam Hansen apud Negt \& Kluge, 1993).

É pertinente trazer aqui o conceito de "esfera pública", que Negt e Kluge trabalharam no livro Esfera pública e experiência a partir da crítica às concepções de Jürgen Habermas sobre os modelos da democracia deliberativa. Para Negt e Kluge, as estruturas decadentes da esfera pública burguesa clássica, isto é, o parlamento, o mercado e outras instâncias que, segundo Habermas, teriam sofrido uma feudalização com o advento do capitalismo moderno, são suplantadas por uma nova esfera pública industrializada, representada pela indústria da consciência e a sua integração vertical. Essa indústria da consciência explora a experiência humana, que é a sua matéria prima, para incorporar ao mercado novas necessidades e qualidades humanas. No entanto, as contradições que gera o próprio avanço da socialização deixam espaço para uma oposição potencial, que pode servir de base para organizações autônomas.

Esses espaços alternativos, ainda que de forma rudimentar e sempre atacados pelo poder da indústria da consciência, surgem nos interstícios e constituem "esferas públicas proletárias". Nesse sentido, o cinema e as novas 
mídias são campos de disputa, nos quais o que está em jogo é a socialização/apropriação da experiência.

Na concepção de Kluge, não existe espectador passivo: todo espectador já é produtor do filme que passa na tela, aportando seu labor emocional, sua fantasia e sua experiência. Mas "essa atividade de recepção não faz ele esquecer quem é que controla os meios de produção, e quem se beneficia da atual organização dos prazeres e pressões do consumo" (Miriam Hansen, p. xxxiv, em Negt e Kluge, 1993). A possibilidade da mídia ser organizada de forma diferente,

no interesse dos sujeitos produtores/experimentadores mais do que no afã de lucro, provê uma base crítica contra os produtos e práticas predominantes. Essa crítica, na visão de Negt e Kluge, não pode limitar-se a uma torre de marfim, se não que deve tomar a forma de "contraproduções", de uma prática concreta da mídia alternativa para intervir na esfera pública contemporânea (Miriam Hansen apud Negt \& Kluge, 1993).

Os embates dos realizadores argentinos, desde essa perspectiva, parecem constituir uma esfera pública alternativa, sobretudo se considerarmos as disputas por espaços de distribuição e exibição, e as resistências que enfrentaram, e continuam a enfrentar atualmente, as propostas de financiamento público para as produções de documentário de baixo orçamento.

Para questionar a pertinência de enquadrar a experiência dos realizadores argentinos como uma esfera pública alternativa, é interessante voltar à entrevista televisiva que o próprio Kluge realizou em fevereiro de 2003 a Fernando Krichmar, um dos realizadores que depois seria contemplado pela Vía Digital, e perguntar-nos: Qual era o interesse do diretor alemão pelo cine piquetero? Para Miriam Hansen,

Em sua ênfase na ecologia da vida pública, o conceito de cinema de Kluge é útil para qualquer prática cinematográfica comprometida com a articulação de discursos sobre experiências marginais, oprimidas, distorcidas e cooptadas, compartam ou não as posições particulares de Kluge (Miriam Hansen apud Kluge, 2012).

O próprio Kluge parece sugerir a possibilidade de que essa produção documental argentina possa impulsionar o surgimento de uma esfera pública alternativa, quando questiona Krichmar em relação às manifestações culturais que acompanharam a rebelião popular de 2001-2002 na Argentina:

AleXANDer Kluge: Nessa situação [dezembro de 2001] ¿Seria possível pensar uma história de amor entre um gerente e uma operária?

FERNANDO KIRCHMAR: Na rebelião do 19 e 20 de dezembro de 2001, as pessoas tinham tal alegria que parecia uma festa orgiástica. Se deram muitas dessas situações. Aquele foi um verão anárquico. 
KLUGE: Se formou uma esfera de cultura alternativa de teatro, de cinema... ¿mas o que aconteceu com a ópera?

[A tradutora aclara: "É que Kluge adora a ópera!"]

KIRCHMAR: Os artistas do Teatro Colón, a maior casa de ópera de Buenos Aires, organizaram-se em assembleia, iam às mobilizações e cantavam o hino nacional num tom operístico, muito estranho numa manifestação ou num bloqueio de rua. É que quando o Fundo Monetário Internacional pede cortes no orçamento da área da cultura, fica claro que as autoridades não entendem por que o Estado tenha que manter um elenco de ópera com recursos públicos. Então, eles também se manifestam.

Da ópera para o cinema, da fábrica para a televisão, dos bairros marginais para a universidade. Esse trânsito intenso entre diferentes âmbitos é algo que se verifica na diversidade temática dos documentários da Vía Digital. Uma produção subalterna, tanto em términos estético-temáticos quanto nas suas práticas produtivas, que busca abrir brechas em meio às alianças empresariais que configuram a indústria da consciência.

A organização dos realizadores e a sua incorporação como sujeitos de direito nas discussões sobre políticas culturais resultou num grande crescimento do documentário, que alcançou a metade da produção argentina. No entanto, as mudanças políticas na região nos últimos anos permitem prever cortes no financiamento das políticas culturais nos países. É possível imaginar que a produção audiovisual de baixo orçamento, "inútil" em termos estritamente econômicos, seja a primeira a receber os ataques das políticas de ajuste neoliberal. Sem dúvida, será necessário fazer avaliações sérias e argumentar sobre a pertinência de políticas de fomento audiovisual mais democráticas.

\section{Referências bibliográficas}

Aguilar, G. et al. (2007). Imágenes de lo real: la representación de lo político en el documental argentino. Buenos Aires: Libraria.

Autran, A. (2004). O pensamento industrial cinematográfico brasileiro. Tese de Doutorado em Multimeios, Campinas: Instituto de Arte da Universidade Estadual de Campinas.

Autran, A. (2013). Sonhos industriais: o cinema dos estúdios na Argentina e no Brasil nos anos 1930. Revista Contracampo: 117-132. Programa de Pós-graduação em Comunicação da Universidade Federal Fluminense (PPGCOM-UFF), Niterói.

Bernardete, J.-C. (1979). Cinema brasileiro: propostas para uma história. Rio de Janeiro: Paz e Terra. 
Braude, D. (2015, Mayo 16). ADN, DOCA y RDI. Haciendo oír las voces del documentalismo. Disponível em: http://recursosculturales.com . Acesso em: 25/05/2016.

Cabral, A. J. C. de B. (2014). Luz, câmera, (concentr)ação!: as políticas públicas e os mercados cinematográficas do Brasil e da Argentina nos anos 1990. Tese de Doutorado em Comunicação e Cultura, Rio de Janeiro: Escola de Comunicação da Universidade Federal do Rio de Janeiro.

Campodónico, R. H. (2005). Trincheras de celuloide: Bases para una Historia Político-Económica del Cine Argentino. Madrid: Fundación Autor, Universidad de Alcalá, Festival Internacional del Nuevo Cine Latinoamericano.

Dodaro, C.; Marino, S. \& Rodríguez, M. G. (2007). Argentina: el caso del cine documental militante durante el ciclo de protesta 2001-2004. Ponencia en el $V$ Congreso Europeo de Latinoamericanistas, Bruselas.

Getino, O. \& Velleggia, S. (2002). El cine de las historias de la revolución. Aproximaciones a las teorías y prácticas del cine "de intervención política” en América Latina (1967-1977). Buenos Aires: Altamira, Museo del Cine Pablo C. Duckós Hicken.

INCAA. (2007 a 2015). Anuario de la Industria Cinematográfica y Audiovisual Argentina. Buenos Aires: INCAA.

Jaime, G. (2015, Abril). Cáncer de Máquina, apuntes del montaje y algo más. La Izquierda Diario. Disponível em: http://laizquierdadiario.com/Cance r-de-maquina-apuntes-del-montaje-y-algo-mas. Acesso em: 23/06/2016.

Kluge, A. \& Negt, O. (2014). History and Obstinacy. New York: Zone Books.

Kluge, A. (2012). Raw Materials for the Imagination. Tara Forrest (ed.), Amsterdam: Amsterdam University Press.

Krieger, C. (2009). Cine y Peronismo: El estado en escena. Buenos Aires: Editorial Siglo XXI.

Krieger, C. (2010). Imágenes políticas, una larga historia. II Congreso Internacional de ASAECA. Disponível em: www.asaeca.org/aactas/kriger_clara .pdf

Krieger, C. (2017). Cinema e Peronismo, documentários estatais e propaganda. Palestra oferecida o 25 de maio de 2017. Programa de PósGraduação em Cinema e Audiovisual (PPGCine), Instituto de Artes e Comunicação Social, Universidade Federal

Machado, A. (2007). Kluge e a televisão. In Almeida, J. (org.), Alexander Kluge: O quinto ato. São Paulo: Cosac Naify. 
Marrone, I. \& Moyano Walker, M. (org.). (2011). Disrupción social y boom documental cinematográfico. Argentina en los años sesenta y noventa. Buenos Aires: Biblos.

Messuti, P. (2014). El impacto de la digitalización en la industria del cine argentino: Políticas de fomento, dinámicas productivas y nuevas ventanas de exhibición. Hipertextos, 2(3). Buenos Aires.

Mestman, M. (2009). La exhibición del cine militante. Teoría y práctica en el Grupo Cine Liberación. In Sel, S. (org.), La comunicación mediatizada: hegemonías, alternatividades, soberanías. Buenos Aires: Consejo Latinoamericano de Ciencias Sociales - CLACSO.

Negt, O. \& Kluge, A. (1993). Public Sphere and Experience: Toward an Analysis of the Bourgeois and Proletarian Public Sphere. Minneapolis: University of Minnesota Press.

Paranaguá, P. A. (ed.). (2003). Cine documental en América Latina. Madrid: Cátedra.

Peña, F. M. \& Vallina, C. (2000). El Cine Quema: Raymundo Gleyzer. Buenos Aires: Ediciones de la Flor.

Russo, P. \& De La Puente, M. (2004). El compañero que lleva la câmara: Cine militante argentino contemporáneo. Buenos Aires: Tierra del Sur.

Sales Gomes, P. E. (2016). Uma situação colonial?.1 Editora Companhia das Letras: São Paulo.

Vinelli, N. \& Rodríguez Esperón, C. (2004). Contrainformación: medios alternativos para la acción política. Buenos Aires: Peña Lillo.

Westhelle, V. (2016). Transfiguring Luther: The Planetary Promise of Luther's Theology. Oregon: Cascade Books.

\section{Filmografia}

Cáncer de máquina (2015, 90 min.), de Alejandro Cohen Arazi e José Binetti. El Ambulante (2009, 84 min.), de Eduardo de la Serna, Lucas Marcheggiano e Adriana Yurcovich.

Elegía de abril (2010, 64 min.), de Gustavo Fontán.

El Rostro de la Dignidad (2001, 60 min.), de Fabián Pierucci, ¿Grupo Alavio.

Hasta donde dea... (2001, 32 min.), de Pablo Navarro Espejo, grupo de cinema Adoquin.

¿Quién mato a Mariano Ferreyra? (2013, 95 min.), de Julián Morcillo e Alejandro Rath, Grupo de Cine Ojo Obrero. 
Seré Millones (2013. 103 min.) de Omar Neri, Fernando Krichmar e Mónica Simoncini.

Un Fantasma recorre la Argentina (2001, 41 min.), realização coletiva do Grupo de Cine Ojo Obrero. 